\title{
PENINGKATAN KEMAMPUAN GURU PAI DALAM UPDATE DATA EMIS OLINE MELALUI BIMTEK PADA MGMP SMK KABUPATEN LOMBOK BARAT
}

\author{
Sukman \\ Kementerian Agama Lombok Barat \\ Email: suryanisukman@gmail.com
}

\begin{abstract}
Abstrak: Penelitian ini bertujuan untuk mengetahui dan memberikan pemahaman kepada Guru PAI dalam pengupdate-an data emis online. Dalam penelitian ini, peneliti menggunakan Metode dan rancangan penelitian tindakan sekolah berdasarkan pada prinsip Kemmis dan Taggart yang mencakup kegiatan perencanaan (planning), pelaksanaan tindakan (action), observasi (observation), refleksi (reflection) atau evaluasi. Keempat kegiatan ini berlangsung secara berulang dalam bentuk siklus. Dari hasil penelitian yang telah dilakukan dapat diambil kesimpulan bahwa kemampuan Guru PAI dalam mengupdate data perlu ditingkatkan. Oleh karena itu dilakukan upaya untuk memberikan pemahaman melalui BIMTEK yang dilaksanakan dengan teknik kelompok dan individual bagi Guru PAI di Kabupaten Lombok Barat terbukti dapat meningkatkan kemampuan guru dalam mengisi dan mengupdate emis online. Hal tersebut dibuktikan dengan peningkatan penilaian instrumen BIMTEK masing-masing guru dalam peningkatan kemampuan guru mengisi dan mengupdate emis online secara individu meningkat pada setiap siklusnya.
\end{abstract}

Kata kunci: Kemampuan Guru PAI, Data Emis Online, MGMP

Title: PAI Teachers 'Ability Improvement in Oline Emis Data Update Through BIMTEK at Vocational School of Vocational School, West Lombok Regency

Abstrack: This research aims to find out and provide understanding to PAI Teachers in updating online EMIS data. In this research, this research uses the method and design of school action research which is carried out with a research procedure based on the Kemmis and Taggart principles which include planning, action, observation, reflection, or evaluation. These four activities take place repeatedly in the form of cycles. From the results of the research that has been done, it can be concluded that the ability of PAI teachers in updating data needs to be improved. Therefore, efforts were made to provide understanding through technical guidance. BIMTEK which is carried out by the group and individual techniques for Islamic Education Teachers in West Lombok Regency is proven to be able to improve the ability of teachers to fill in and update online EMIS. This is evidenced by an increase in the assessment of BIMTEK instruments for each teacher. In increasing the ability of teachers to fill and update the online EMIS individually increasing in each cycle.

Keyword: Ability of PAI Teachers, Online EMIS Data, MGMP 


\section{PENDAHULUAN}

Sistem informasi manajemen merupakan kebutuhan yang diperlukan dalam suatu organisasi untuk mencapai efektifitas dan efisensi kerja, khususnya dalam era perkembangan teknologi seperti saat ini. Perkembangan teknologi mendorong adanya pengembangan pengelolaan administrasi organisasi dari sistem tradisional menjadi sistem berbasis teknologi informasi. Salah satu manfaat dari sistem informasi manajemen dalam organisasi adalah sebagai sarana pengambilan keputusan. Administrasi pada hakikatnya adalah pengambian keputusan. ${ }^{1}$ Karena setiap kegiatan di dalam organisasi pasti terdapat permasalahan yang harus diselesaikan, baik dengan cara demokratis maupun menggunakan otoritas pimpinan. Keputusan yang baik memerlukan pemahaman tentang masalah dan pengetahuan tentang alternatif pemecahannya. Ketepatan dan keakuratan informasi yang baik akan mempengaruhi pengambilan keputusan yang baik pula. ${ }^{2}$ Oleh karena itu pemanfaatan sistem informasi manajemen sangatlah penting agar kebijakan yang diambil sesuai dengan kebutuhan yang didasarkan pada data yang tepat dan akurat. $^{3}$

Merupakan suatu langkah maju bagi perkembangan manajemen khususnya bidang Pendidikan Islam telah mempunyai sistem informasi manajemen yang dirancang dan dikembangkan oleh Direktorat Jenderal Kelembagaan Agama Islam yang dikenal sebagai EMIS (Education Management Information System). Perancangan dan pengembangan EMIS diharapkan dapat dijadikan sebagai penyedia data dan informasi yang dibutuhkan dalam perumusan kebijakan, penyusunan anggaran, pengambilan keputusan, perencanaan penyelenggaraan pendidikan, dan pengembangan pendidikan agama. ${ }^{4}$

EMIS dirancang untuk mengatur data dan informasi dalam skala besar yang kemudian dapat dibaca, diambil kembali, diproses, dianalisis dan disajikan untuk digunakan dan disebarkan. ${ }^{5}$ Seksi Pendidikan Agama dan Keagamaan Islam (PAKIS) merupakan salah satu seksi dalam jajaran organisasi Kementerian Agama Kabupaten Lombok Barat yang memiliki tugas melakukan pelayanan dan bimbingan teknis, pembinaan serta pengelolaan data dan informasi di bidang Pendidikan Agama Islam pada PAUD, SD / SDLB, SMP / SMPLB, SMA / SMALB / SMK. ${ }^{6}$ Dalam praktik pengelolaan data dan informasinya, seksi ini dibantu oleh

\footnotetext{
${ }^{1}$ Ibnu Syamsi, Pengambilan Keputusan Dan Sistem Informasi (Bumi Aksara, 1995), 89.

2 Ibid., 100.

3 Fuadi Aziz, "Pengambilan Kebijakan Berbasis Education Management Information System (EMIS)," Jurnal Pendidikan Islam 3, no. 1 (2014): 135-162.

${ }^{4}$ Dodi Irawan dan Rosidin Syarip, Sistem Manajemen Data Dan Informasi Pendidikan Di Lingkungan Direktorat Jenderal Kelembagaan Agama Islam (Jakarta: Departemen Agama RI; Direktorat Jenderal Kelembagaan Agama Islam, 2003), 26-27.

${ }^{5}$ Ibid., 20.

${ }^{6}$ Kementerian Agama Kantor Kabupaten page/ pais.html, [13 April 2016]. Lombok Barat, http: // www. kemenaggeka. net/
} 
beberapa orang staf dan stackhoulder yang salah satunya adalah Pengawas Pendidikan Agama Islam.

Data EMIS diperbaharui secara berkala setiap semester. Hal ini bertujuan agar dapat memperoleh informasi-informasi terbaru sehingga mempermudah kepala seksi dalam mengontrol dan menganalisis informasi sebagai bahan pengambilan keputusan tapi dalam praktiknya di lapangan banyak kendala yang dihadapi, Adapun kendala yang dihadapi oleh seksi PAI dalam mengumpulkan data EMIS saat ini adalah pengumpulan data dari beberapa guru agama yang lamban,banyak guru yang belum bisa mengisi dan meng-update data emisnya sehingga tidak sesuai dengan yang diharapkan, sehingga mereka tidak melengkapi data EMIS tepat waktu. Hal ini menyebabkan keterlambatan terkumpulnya data dari jadwal yang telah ditentukan.

Dalam usaha meningkatkan kualitas sumber daya pendidikan, guru merupakan komponen sumber daya manusia yang harus dibina dan dikembangkan terus menerus. Untuk itu, agar para guru PAI mampu melaksanakan tugas-tugas yang menjadi tanggung jawabnya di sekolah dan mampu mengisi dan meng-update data emisnya perlu senantiasa mendapat penyegaran dalam bentuk bantuan teknis atau pelatihan -pelatihan. Bantuan teknis ini diberikan kepada guru sebagai upaya peningkatan kapasitas secara terus menerus. Bantuan tersebut dalam bentuk Bimbingan dan Pelatihan yang dilakukan oleh pengawas dalam hal ini pengawas Pendidikan Agama Islam.

Bimbingan dan Pelatihan adalah serangkaian kegiatan membantu guru mengembangkan kemampuannya mengelola proses pembelajaran demi pencapaian tujuan pembelajaran. Dengan demikian, Bimbingan dan Pelatihan merupakan kegiatan terencana yang ditujukan pada aspek kualitatif sekolah dengan membantu guru melalui dukungan dan evaluasi pada proses belajar dan pembelajaran yang dapat meningkatkan hasil belajar. Supervisi atau pembinaan guru tersebut lebih menekankan pada "Pembinaan profesional guru" yakni pembinaan yang lebih diarahkan pada upaya memperbaiki dan meningkatkan kemampuan profesional guru. Guru yang profesional amat berarti bagi pembentukan sekolah unggulan. Guru profesional memiliki pengalaman mengajar, kapasitas intelektual, moral, keimanan, ketaqwaan, disiplin, tanggungjawab, wawasan kependidikan yang luas, kemampuan manajerial, terampil, kreatif, memiliki keterbukaan profesional dalam memahami potensi, karakteristik dan masalah perkembangan peserta didik, mampu mengembangkan rencana studi dan karir peserta didik serta memiliki kemampuan meneliti dan mengembangkan Kurikulum.

Tujuan Bimbingan dan Pelatihan adalah membantu guru mengembangkan kemampuannya mengisi dan meng-update data emis setiap semester. Melalui Bimbingan dan Pelatihan diharapkan kualitas akademik yang dilakukan oleh guru semakin meningkat. 
Sebagai salah satu sumber acuan dalam pengembangan profesional tenaga kependidikan (khususnya guru Pendidikan Agama Islam), penting rasanya diefektifkan dimensi kompetensi Bimbingan dan Pelatihan oleh pengawas sekolah dengan memaksimalkan kegiatan Bimbingan dan Pelatihan diharapkan tenaga guru dapat meningkatkan pengetahuan dan keterampilan dalam proses pembelajaran.

Bimbingan dan Pelatihan merupakan kegiatan terencana yang ditujukan pada aspek kualitatif sekolah dengan membantu guru melalui dukungan dan evaluasi pada proses pembelajaran yang dapat meningkatkan hasil belajar dan memberi jawaban pada pertanyaan bagaimana siswa belajar lebih baik. Dukungan dan evaluasi merupakan dua fungsi utama untuk tipe Bimbingan dan Pelatihan. Tujuan Bimbingan dan Pelatihan adalah meningkatkan mutu pembelajaran sedangkan fungsi dukungan dalam Bimbingan dan Pelatihan adalah menyediakan bimbingan profesional dan bantuan teknis pada guru untuk meningkatkan kinerja dalam proses pembelajaran. Dengan mengajar lebih baik berarti membantu siswa untuk lebih mudah mencapai kompetensi yang harus dikuasai dalam pembelajaran. Semestinya semakin sering dilaksanakan Bimbingan dan Pelatihan oleh pengawas sekolah terhadap guru Pendidikan Agama Islam dapat meningkatkan secara signifikan kualitas kinerja guru Pendidikan Agama Islam dalam proses pembelajaran.

Diharapkan dengan adanya Bimbingan dan Pelatihan, hasil dari pelaksanaan proses pembelajaran akan lebih baik dan bermutu. dalam upaya mencetak kualitas output yang lebih baik. Oleh karena itu, sekolah, sebagai institusi formal yang diharapkan dapat mencetak siswa yang berkualitas, harus dijalankan oleh para pendidik dan tenaga kependidikan yang memiliki profesionalisme yang tinggi untuk memajukan sekolah.

Berdasarkan pengamatan selama satu tahun terakhir, terlihat dari sebagian guru Pendidikan Agama Islam belum mampu mengisi dan meng-update data emisnya khususnya data emis yang sudah berbentuk online. Untuk mengatasi masalah tersebut, penelitian ini akan melakukan tindakan berupa Bimbingan dan Pelatihan (BIMTEK), agar motivasi serta profesionalisme guru Pendidikan Agama Islam terutama dalam mengisi emis online dapat meningkat dengan baik.

\section{METODE PENELITIAN}

Metode dan rancangan penelitian tindakan sekolah ini dilakukan dengan prosedur penelitian berdasarkan pada prinsip Kemmis dan Taggart ${ }^{7}$ yang mencakup kegiatan sebagai berikut: perencanaan (planning), pelaksanaan tindakan (action), observasi (observation), refleksi (reflection) atau evaluasi. Keempat kegiatan ini berlangsung secara berulang dalam bentuk siklus. Subyek penelitian adalah guru pendidikan Agama Islam Tingkat SMK yang berada di

\footnotetext{
${ }^{7}$ Kemmis dan Mc Taggart, The Action Research Planner (Victoria: Deaklin University, 1998), 10.
} 
Kabupaten Lombok Barat sebanyak 18 orang guru yang merupakan perwakilan dari masingmasing Kecamatan dan sebagian besar dari guru-guru tersebut berasal dari guru-guru yang mengajar di Sekolah swasta dan berstatus honorer(non PNS). Dikarenakan penelitian ini meripakan penelitian kualitatif, maka teknik pengumpulan data dalam penelitian ini dilakukan pada natural setting (kondisi yang alamiah), sumber data primer, dan teknik pengumpulan data lebih banyak pada observasi berperanserta (participan observation), dan dokumentasi.

Selanjutnya dalam sebuah penelitian, validitas data merupakan suatu tingkat atau derajat ketepatan antara data yang terjadi pada objek penelitian dengan data yang dilaporkan oleh peneliti. Dengan demikian data yang valid adalah data yang tidak berbeda antara data yang dilaporkan oleh peneliti dengan data yang sesungguhnya terjadi pada objek penelitian di lapangan. Data dalam penelitian harus memenuhi standar keabsahan, oleh karena itu peneliti harus mengadakan uji terhadap keabsahan data yang diperoleh dari kepala sekolah yaitu dengan melalui uji kredibilitas data. Pengujian kredibilitas data atau kepercayaan terhadap data hasil penelitian akan dilakukan dengan triangulasi data. Triangulasi dalam pengujian kredibiltas diartikan sebagai pengecekan data dari berbagai sumber dengan berbagai cara dan berbagai waktu. Dalam penelitian ini, peneliti menggunakan 2 jenis triangulasi ${ }^{8}$ yakni triangulasi sumber dan triangulasi tekhnik. Triangulasi sumber untuk menguji kredibilitas data dilakukan dengan cara mengecek data yang diperoleh melalui beberapa sumber. Sedangkan tringulasi teknik untuk menguji kredibilitas data dilakukan dengan cara mengecek data kepada guru pendidikan Agama Islam yang sama dengan teknik yang berbeda

Adapun teknik analisa data yang menjadi pedoman pengolahan data oleh penulis, mengacu kepada pendapat M. Ngalim Purwanto ${ }^{9}$ dengan rumus sebagai berikut: $\mathrm{P}=\mathrm{R} / \mathrm{T}$ x 100. Labih lanjut Suharsimi Arikunto ${ }^{10}$ (2010: 269) menjelaskan analisis data deskriptif kualitatif yaitu sebagai berikut: Analisis data yang menggunakan teknik deskriptif kualitatif memanfaatkan persentase merupakan langkah awal saja dari keseluruhan proses analisis. Persentase yang dinyatakan dalam bilangan sudah jelas merupakan ukuran yang bersifat kuantitatif, bukan kualitatif. Jadi pernyataan persentase bukan hasil analisis kualitatif. Analisis kualitatif tentu harus dinyatakan dalam sebuah predikat yang menunjuk pada pernyataan keadaan, ukuran kualitas. Adapun analisis data secara deskriptif kualitatif dalam penelitian ini adalah memaknai data dengan cara membandingkan hasil dari sebelum dilakukan tindakan dan sesuadah tindakan. Analisis data ini dilakukan pada saat tahapanrefleksi. Hasil analisis digunakan sebagai bahan refleksi untuk melakukan perencanaan lanjut dalam siklus selanjutnya.

${ }^{8}$ Sugiyono, Metode Penelitian Kuantitatif Kualitatif Dan R\&D (Bandung: Alfabeta, 2012), 241.

${ }^{9}$ M. Ngalim Purwanto, Evaluasi Dan Supervisi Pendidikan (Jakarta: Fakultas Ilmu Pendidikan, 1987), 172.

${ }^{10}$ Suharsimi Arikunto, Research Procedure a Practical Approach (Jakarta: Rineka Cipta, 2010), 269. 


\section{TEMUAN DAN PEMBAHASAN}

\section{Pengertian, Fugsi dan cara Update EMIS}

Management Information System (EMIS) adalah sebuah yang akurat dan tepat waktu sehingga proses pengambilan keputusan, perencanaan, pengembangan proyek, dan fungsifungsi manajemen pendidikan lainnya dapat dilaksanakan secara efektif. Dalam pengertian lain EMIS adalah sekelompok informasi dan dokumentasi yang terorganisasi dalam melaksanakan pengumpulan, penyimpanan, pengolahan, analisis, dan penyebaran informasi yang digunakan untuk manajemen dan perencanaan pendidikan. ${ }^{11}$ Sistem EMIS digunakan untuk mengatur data dan informasi pendidikan dalam jumlah besar yang dapat dibaca, diambil kembali, diproses, dianalisis, disajikan dan disebarkan. ${ }^{12}$

Kementrian Agama yang bertanggung jawab terhadap pelaksanaan pendidikan Agama madrasah dan sekolah dalam pendataannya telah menggunakan sistem informasi manajemen pendidikan yang dikenal dengan EMIS (Education Management Information System). ${ }^{2}$ EMIS yang digunakan dalam lingkungan Kementrian Agama berisi informasi yang dibutuhkan dalam pengambilan keputusan bidang pendidikan. Sistem ini merekam tentang jumlah lembaga, pendidik dan tenaga kependidikan, fasilitas yang dimiliki, dan lain-lain. Sebagaimana pedoman pelaksanakan EMIS yang diatur oleh Kementerian Agama bahwa indikator (statistik) pendidikan yang sering digunakan dalam analisis data EMIS adalah Rasio Jumlah Murid Kasar (Gross Enrolment Ratio), Angka Partisipasi (Participation Rate), Angka Penyerapan Kasar (Gross Intake Rate), Angka Penyerapan Bersih (Net Intake Rate), Angka Daya Tahan Cohort (Cohort Survival Rate), Angka Penyelesaian (Completion Rate), Angka Kelulusan (Graduation Rate), Angka Transisi (Transition Rate), Angka

Kehadiran sistem EMIS ini diharapkan data-data yang masuk dapat lebih akurat dan terus menerus dapat diperbaharui (update) sehingga dapat digunakan sebagai dasar pengambilan keputusan. Sejauh ini, 87\% data EMIS menentukan kualitas perencanaan, sehingga harus terus ditingkatkan dengan meminimalisir berbagai kelemahan yang terjadi selama ini. ${ }^{13}$

Idealnya pengambilan keputusan membutuhkan sumber data yang valid dan mudah untuk dibaca. Data yang valid dan mudah dibaca dibutuhkan sebagai bahan pertimbangan yang digunakan dalam setiap pengambilan kebijakan ataupun pengambilan keputusan yang dibatasi oleh waktu. Karenanya peran data dalam pengambilan keputusan sangat penting.

11 Syarip, Sistem Manajemen Data Dan Informasi Pendidikan Di Lingkungan Direktorat Jenderal Kelembagaan Agama Islam, 20.

${ }_{12}$ Charles C Villanueva, "Education Management Information System (Emis) and the Formulation of Education for All (Efa) Plan of Action," Unesco 1, no. 1 (2003): 6.

13 Syarip, Sistem Manajemen Data Dan Informasi Pendidikan Di Lingkungan Direktorat Jenderal Kelembagaan Agama Islam, 21. 
EMIS digunakan sebagai pendukung pengambilan keputusan dalam lembaga pendidikan. Sistem ini akan mengatur dan mengelola sesuai dengan kebutuhan lembaga pendidikan. Contoh secara umum penyediaan data tentang jumlah kapasitas sekolah dari mulai tingkat dasar sampai perguruan tinggi, baik swasta maupun negeri. Perencanaan jumlah kelas, siswa, dan SDM untuk tenaga pendidikan negeri/PNS akan tunduk pada peraturan pemerintah yang sudah baku dilaksanakan, mulai dari data pelamar, peraturan pemerintah yang berkaitan dengan rekruitmen tenaga kependidikan PNS, peningkatan jenjang karir, program pengembangan yang didasarkan atas dasar data keterampilan yang dimiliki tenaga kependidikan, pendidik pelatihan dan penilaian prestasi kerja, serta besarnya kompensasi berdasarkan acuan yang telah dibuat oleh pemerintah. EMIS akan sangat berguna untuk dapat menyederhanakan kegiatan administrasi seperti pembuatan laporan rutin, persiapan jumlah kelas, persiapan jumlah tenaga pendidik dan kependidikan, perencanaan sarana dan prasarana yang memadai sehingga proses KBM berjalan dengan efektif dan efisien.

Pemanfaatan EMIS dalam pengambilan keputusan di seksi PAI Kementerian Agama Kabupaten Lombok Barat sudah sesuai dengan tujuan diterapkannya aplikasi tersebut dalam membantu kegiatan manajemen pendidikan di lingkungan Kementerian Agama. Hal ini terlihat dari sebagian besar keputusan yang dirumuskan telah memanfaatkan data pendidikan islam yang terdapat dalam data base aplikasi EMIS sebagai informasi bahan analisis perumusan alternatif kebijakan seperti penentuan jumlah guru peserta sertifikasi, penyusunan anggaran, penyusunan program pendidikan, pemerataan dan pemenuhan jam mengajar guru, serta keputusan pendidikan lain yang memanfaatkan informasi EMIS.

Data EMIS sangat menunjang pengambilan keputusan. Didukung dari kecakapan operator EMIS yang mampu menyajikan data secara maksimal dan kemampuan kepala seksi PAI dalam menggunakan metode pendekatan personal sehingga keputusan yang dihasilkan dari analisis data dan pendekatan personal merupakan keputusan yang terbaik dan dapat diterima oleh semua pihak

Pada awal diluncurkan aplikasi Emis oleh Kementerian Agama masih menggunakan format manual,kemudian seiring dengan semakin pesatnya perkembangan teknologi ,Format emis sejak tahun 2018 Emis sudah dapat diisi dan diupdate secara online, pengisian EMIS Online sampai saat ini memang masih belum maksimal. Sebab terdapat fitur yang belum bisa digunakan. Akibatnya banyak dari para operator kebingungan mengenai apa yang harus dikerjakan. Mengingat belum bisa menambahkan data peserta didik baru ke dalam EMIS

Jika kita melihat Juknis Update EMIS Online Tahun Pelajaran 2017/2018, di situ dijelaskan bahwa salah satu hal penting yang harus dilakukan ialah mengupdate data siswa. Apa yang dimaksud dengan mengupdate data siswa itu. Yang dimaksud dengan update data siswa adalah memperbarui dan melengkapi data siswa sesuai dengan form EMIS Online yang disediakan. Sehingga diharapkan data peserta didik akan menjadi lengkap. Ada beberapa data 
siswa yang harus diisi di dalam Aplikasi EMIS Online. Misalnya saja Nama Lengkap, Nomor Induk Siswa Nasional (NISN) hingga Nomor Induk Kependudukan (NIK). Lalu bagaimana cara mengupdate data siswa di dalam Aplikasi EMIS Online. Untuk bisa mengupdate data siswa di dalam Aplikasi EMIS Online, caranya adalah sebagai berikut: Pastikanlah bahwa laptop/komputer sudah terkoneksi dengan internet secara baik; Bukalah web Browser di laptop / komputer anda; Masukkan alamat EMIS Madrasah ke Tab browser anda yang beralamat sebagai berikut:htttps://emispendis.kemenag.go.id/emis_madrasah; Silahkan anda lakukan Login dengan menggunakan Username dan Password yang telah diaktifkan; Setelah berhasil melakukan login, anda akan di bawa masuk ke dala Menu utama aplikasi EMIS Online; Untuk melakukan Update data siswa, silahkan anda pilih Menu "Siswa Aktif' yang berada di sebelah kiri; Maka kemudian akan tampil data siswa yang aktif di sekolah anda (bisa anda lihat pada gambar di atas); Klik pada tombol pensil di sebelah kanan untuk melihat informasi detail setiap peserta didik; Lengkapi semua data peserta didik yang ada satu persatu sampai dengan selesai; dan Setelah selesai, Klik Tombol Simpan

\section{Pengertian, Tujuan dan Materi BIMTEK (Bimbingan Tehnis)}

Definisi Pelatihan/Bimbingan Teknis (Bimtek) adalah suatu kegiatan dimana para peserta diberi pelatihanpelatihan yang bermanfaat dalam meningkatkan kompetensi peserta yang dimana materi yang diberikan meliputi Membangun Tim Kerja Efektif, Teknik Komunikasi dalam Konteks Pelayanan Prima, Survey Indeks Kepuasan Masyarakat dan Penanganan Keluhan Pelanggan, Tata Pemerintahan yang Baik dan Profesionalisme Aparatur, Kepemimpinan, dan lain-lain. ${ }^{14}$ Beberapa tujuan dari Bimbingan Teknis Secara Umum, meliputi: Peningkatan kualitas Sumber Daya manusia; Koordinasi yang lebih baik; Peningkatan kinerja institusi dan organisasi untuk menunjang keberhasilan suatu institusi; Memiliki kompetensi untuk secara optimal melaksanakan tugas jabatan yang diduduki; Memiliki kompetensi untuk menduduki jabatan yang lebih tinggi. Materi Bimtek yang dapat diberikan sangat beragam dan terus bertambah seiring dengan perkembangan jaman, yang harus menjadi perhatian dari peserta Bimtek adalah siapa Lembaga penyelenggara Bimtek. Peserta Bimtek harus memperhatikan kredibilitas atau izin dari penyelenggara tersebut. Lembaga mengadakan Bimbingan Teknis tanpa izin yang jelas dapat mengakibatkan ketidak jelasan materi yang akan didapat peserta yang tentunya akan berdampak pada tidak terpenuhinya tujuan dari keikutsertaan bimbingan teknis. Tujuan akhir dari keikutsertaan peserta dalam bimbingan teknis menjadi sangat penting baik bagi individu ataupun bagi instansi tempat mengabdi.

14 "Manual Prosedur Bimbingan Teknis (BIMTEK)" (Malang: Lembaga Penelitian dan Pengabdian Kepada Masyarakat (LPPM) Universitas Brawijaya Malang, 2015), 3-4. 


\section{Musyawarah Guru Mata Pelajaran Pendidikan Agama Islam}

Organisasi adalah suatu kelompok orang dalam suatu wadah untuk tujuan bersama. Adapun unsur dasar suatu organisasi adalah terdapatnya sekumpulan orang, kerjasama dan tujuan yang ingin dicapai. Dengan demikian tujuan organisai profesi ${ }^{1}$ merupakan sarana untuk melakukan kerjasama antara orang-orang atau pengurus, anggota MGMP, dan teman sejawat, dalam rangka mencapai tujuan bersama, yaitu sesuai dengan tujuan dan fungsi dibentuknya MGMP. Sedangkan organisasi Musyawarah Guru Mata Pelajaran (MGMP) Pendidikan Agama Islam adalah wadah yang berfungsi sebagai wahana komunikasi, informasi diskusi dan pembinaan sesama guru pendidikan agama Islam. Tujuan pendidikan agama Islam ialah pembentukan watak, kepribadian muslim, yaitu suatu kepribadian yang seluruh aspeknya dijiwai oleh ajaran Islam.

Forum komunikasi antara sesama GPAI untuk meningkatkan kemampuan profesional dan fungsional, forum konsultasi berkaitan dengan kegiatan pembelajaran,khususnya yang menyangkut materi pembelajaran, metodologi, sistem evaluasi, dan sarana penunjang, forum penyebarluasan informasi tentang segala kebijakan yang berkaitan dengan usaha-usaha pembaharuan dalam bidang pendidkan. Musyawarah Guru Mata Pelajaran (MGMP) merupakan wadah bagi guru mata pelajaran untuk meningkatkan kemampuannya, dalam melaksanakan kegiatan pendidikan, dan pembelajaran. Untuk itu, maka guru harus dapat memiliki kualifikasi dan kemampuan dasar yang diorientasikan pada peningkatan kualitas pengetahuan, penguasaan materi, teknik mengajar, interaksi guru dengan peserta didik, dan metode mengajar yang berfokus pada pencintaan kegiataan pembelajaran yang aktif. Adapun jenis kegiatan Musyawarah Guru Mata Pelajaran sesuai dengan pedoman MGMP terdiri atas:

1. Kegiatan pengembangan potensi keterampilan guru, melalui penguasaan kurikulum. penyusunan program tahunan dan semester, penyusunan perangkat pembelajaran, dan penguasaan materi yang esensial.

2. Kegiatan wawasan, antara lain ; mengadakan seminar atau lokakarya, dan mengadakan lomba penulisan karya ilmiah.

3. Kegiatan penunjang antara lain mengadakan penelitian.

\section{Kerangka Pikir MGMP PAI}

Musyawarah Guru Mata Pelajaran Agama (MGMP PAI SMK) adalah forum yang digunakan sebagai forum komunikasi guru sekolah dasar dalam usaha pembinaan dan mengembangkan profesionalitas guru dalam meningkatkan mutu pendidikan. Forum ini memiliki tujuan salah satunya sebagai tempat untuk berdiskusi dalam berbagi informasi, inovasi, dan menjadi tempat untuk memecahkan masalah dalam peningkatan mutu pendidikan serta wahana berkumpulnya guru untuk bersama-sama menyusun perencanaan, 
pelaksanaan serta penilaian pembelajaran. Pemecahan masalah ini guru hendaknya memiliki kompetensi yang harus dimiliki guru sesuai dengan PP. Nomor 19 Tahun 2005 tentang Standar Nasional Pendidikan Menyebutkan ada empat kompetensi guru yaitu kompetensi pedagogik, kompetensi kepribadian, kompetensi profesional, dan kompetensi sosial (Darmadi, 2010: 31). Sehingga dengan MGMP PAI SMK ini dapat dijadikan suatu forum yang digunakan sebagai tempat diskusi dan peningkatan mutu pendidikan yang dapat menunjang kompetensi guru. Kompetensi pedagogik merupakan kompetensi yang berkaitan dengan pembelajaran di dalam kelas, karena kompetensi pedagogik mengandung aspek salah satunya adalah kemampuan dalam perancangan dan pelaksanaan pembelajaran yang sangat penting dalam pembelajaran di dalam kelas.

Kegiatan MGMP PAI SMK merupakan forum yang berfungsi sebagai tempat berdiskusi diharapkan dapat dimanfaatkan oleh guru untuk memperluas pengetahuannya serta dapat meningkatkan kompetensi dan keterampilannya terutama salah satunya adalah dalam upaya meningkatkan kemampuan guru dalam melakukan penelitian dan penulisan karya ilmiah khususnya penelitian tindakan kelas. Maka dari dari kerangka berfikir di atas maka peneliti berasumsi bahwa kegiatan MGMP PAI SMK dapat bermanfaat dalam peningkatan kemampuan guru dalam melakukan penelitian dan penulisan karya ilmiah khususnya penelitian tindakan kelas khususnya pada Kabupaten II Kecamatan Sawan.

Dalam bentuk bagan, kerangka pikir pelaksanaan penelitian tindakan sekolah melalui pengintesifan kegiatan MGMP PAI SMK dalam upaya peningkatan kemampuan guru dalam melakukan penelitian dan penulisan karya ilmiah khususnya penelitian tindakan kelas sebagaimana gambar di bawah ini. metode manajemen formal dalam penyediaan informasi pendidikan

\section{Peningkatan Kemampuan Guru PAI Dalam Mengupdate Data Emis Oline Melalui Bimtek}

Pada hakikatnya Bimbingsn Teknis yang disingkat Bimtek bertujuan memberikan bantuan kepada guru agar dapat memperbaiki kekurangan atau kelemahan dalam proses pembelajaran serta dapat mengembangkan kompetensi yang dimilikinya secara individual maupun kelompok dalam upaya meningkatkan mutu pembelajaran. Bimtek bukanlah yang semata-mata untuk menilai kegiatan pembelajaran yang dilaksanakan oleh guru. Penilaian yang dilaksanakan baik menggunakan instrumen supervisi maupun obsevasi kelas agar dianalisis terlebih dahulu permasalahannya, kemudian digunakan sebagai bahan tindak lanjut untuk membina dan membimbing guru pendidikan Agama Islam dalam rangka meningkatkan kualitas pembelajaran, sehingga diperoleh hasil belajar peserta didik yang maksimal. Tanggapan sebagian guru pendidikan Agama Islam terhadap Bimtek itu, sebenarnya baik sekali bila dilaksanakan secara terprogram dan kontinyu. 
Apabila kegiatan Bimtek ini sudah dirasakan manfaatnya dari guru maka kegiatan ini tidak akan menjadi beban, baik bagi pengawas sekolah maupun guru tetapi sudah menjadi suatu kebutuhan untuk memperbaiki situasi belajar dan mengajar di sekolah. Oleh karena itu, bukan suatu hal yang mudah untuk mencapai tujuan Bimtek, tentu diperlukan perencanaan atau program yang objektif dan berkesinambungan. Namun tidak cukup hanya memiliki program yang baik, tetapi suatu program yang baik itu harus dapat dilaksanakan dan ditindaklanjuti secara baik pula.

Banyak pengawas sekolah sudah menyusun program, tetapi tidak dapat dilaksanakan. Untuk apa menyusun program kalau hanya melengkapi dokumen saja. Konsep pengawas sekolah sebagai supervisor harus menunjukkan adanya perbaikan dalam pembelajaran pada sekolah yang dipimpinnya akan tampak setelah dilakukan sentuhan supervisor berupa bantuan untuk mengatasi kesulitan guru dalam mengajar. Untuk itulah pengawas sekolah perlu memahami program dan strategi pengajaran, sehingga ia mampu memberi bantuan kepada guru pendidikan Agama Islam yang mengalami kesulitan misalnya dalam menyusun program dan strategi pengajarannya masing-masing. Bantuan yang diberikan oleh pengawas sekolah kepada guru berupa bantuan dukungan fasilitas, bahan-bahan ajar yang diperlukan, penguatan terhadap penguasaan materi dan strategi pengajaran, pelatihan-pelatihan serta bantuan lain yang akan meningkatkan efektivitas program pengajaran dan implementasi program dalam aktivitas belajar di kelas.

Secara rutin dan terjadwal pengawas sekolah melaksanakan kegiatan supervisi kepada guru-guru pendidikan Agama Islam dengan harapan agar guru mampu memperbaiki proses pembelajaran yang dilaksanakan. Dalam prosesnya, pengawas sekolah memantau secara langsung ketika guru sedang mengajar. Guru mendesain kegiatan pembelajaran dalam bentuk rencana pembelajaran kemudian pengawas sekolah mengamati proses pembelajaran yang dilakukan guru pendidikan Agama Islam. Sebelum melaksanakan Bimtek terhadap guru, sebaiknya pengawas sekolah melakukan langkah-langkah (1) menyusun program Bimtek, dalam menyusun program Bimtek harus secara sistematis dan berkesinambungan, serta melibatkan guru, dengan tujuan guru mengetahui dan memahami tujuan dilaksanakan supervisi, bukan untuk menilai dan mencari kesalahan pada guru. Tetapi untuk membantu dan memperbaiki kekurangan yang ada pada guru dalam proses pembelajaran di sekolah. Dengan dilibatkannya guru dalam menyusun program supervisi berarti mereka turut bertanggung jawab atas keterlaksanaannya. (2) mensosialisasikan program Bimtek, setelah program Bimtek disusun oleh pengawas sekolah, sebaiknya disosialisasikan kepada guru-guru atau tenaga kependidikan lainnya dengan memberikan pengertian dan tujuan supervisi, jadwal supervisi, dan instrumen supervisi yang akan digunakan. Bila perlu diberikan jadwal supervisi dan instrumen supervisi dengan harapan guru-guru sudah mengetahui dan mempelajarinya sejak dini, akhirnya tidak terjadi kesalahpahaman antara pengawas sekolah dan guru dalam 
pelaksanaan supervisi di sekolah. (3) melaksanakan Bimtek, sebelum melaksanakan supervisi terhadap guru maka seorang supervisor harus memahami terlebih dahulu prinsip-prinsip, tujuan, teknik-teknik dan pendekatan supervisi. Hal ini penting agar dapat melaksanakan supervisi secara baik dan menyenangkan, sehingga keharmonisan hubungan dan antara pengawas sekolah dan guru akan terjalin secara kekeluargaan. (4) tindak lanjut hasil supervisi, kegiatan akhir setelah melaksanakan supervisi terhadap guru, seorang supervisor diharapkan menganalisis hasil Bimtek yang telah dilakukan kepada guru dan memberikan umpan balik atau tindak lanjut berupa pembinaan, penguatan atau penghargaan (reward) dan saran-saran untuk perbaikan dalam proses kegiatan belajar mengajar di sekolah.

Kegiatan tindak lanjut merupakan lanjutan dari kegiatan pelaksanaan supervisi yang telah dilakukan. Untuk itu instrumen penilaian dan catatan tentang kelebihan dan kekurangan guru perlu dicatat atau direkam secara objektif oleh pengawas sekolah. Manfaatnya dari hasil penilaian dan catatan-catatan itu, nantinya dapat digunakan untuk mengadakan pembinaan baik secara individu maupun bersama sama di sekolah binaan. Pengawas sekolah harus melakukan tindak lanjut hasil Bimtek dengan cara-cara : (a) meninjau kembali (review) rangkuman hasil supervisi, (b) melakukan pembinaan terhadap guru baik secara individual maupun kelompok. Langkah-langkah pembinaan kemampuan guru melalui Bimtek yaitu menciptakan hubungan yang harmonis, analisis kebutuhan guru, mengembangkan strategi dan media pembelajaran, menilai kemampuan guru, dan merevisi program pembimbingan.

Hasil pembimbinan itu perlu ditindaklanjuti agar memberikan dampak yang nyata untuk meningkatkan profesionalisme guru pendidikan Agama Islam . Selain itu, perlu melakukan cara-cara dalam menindaklanjuti Bimtek sehingga menghasilkan dampak nyata yang diharapkan dapat dirasakan masyarakat atau stakeholders. Tujuan kegiatan tindak lanjut agar guru pendidikan Agama Islam menyadari kelemahan atau kekurangannya dalam proses pembelajaran, sehingga para guru pendidikan Agama Islam berusaha memperbaikinya melalui pembinaan atau kegiatan keprofesian seperti pelatihan, seminar, kegiatan MGMP, dan lain-lainnya.

Melihat analisis data hasil penelitian tentang peningkatan kemampuan guru pendidikan Agama Islam di Kabupaten Lombok Barat dalam mengupdate emis online maka dapat disimpulkan bahwa penerapan program pembinaan dengan pelaksanaan Bimtek yang dilakukan secara berkelompok dan individual terbukti dapat meningkatkan kemampuan guru pendidikan Agama Islam di Kabupaten Lombok Barat dalam mengupdate emis online.

\section{SIMPULAN}

Berdasarkan data yang telah dikumpulkan di atas, serta telah dilakukannya analisis dapat ditarik suatu kesimpulan untuk menjawab permasalahan penelitian sebagai berikut : 
Pertama, bimtek yang dilaksanakan dengan teknik kelompok dan individual bagi guru Pendidikkan Agama Islam di Kabupaten Lombok Barat terbukti dapat meningkatkan kemampuan guru dalam mengisi dan mengupdate emis online. Hal tersebut dibuktikan dengan peningkatan penilaian instrumen Bimtek masing-masing guru . Kedua, peningkatan kemampuan guru dalam mengisi dan mengupdate emis online secara individu meningkat pada setiap siklusnya. Pada kondisi awal tidak ada satupun guru yang dinyatakan mampu mengisi dan mengupdate emis online dengan baik, pada siklus pertama meningkat menjadi 7 orang guru atau 42,00\%, dan 100\% atau semua guru dinyatakan mampu mengisi dan mengupdate emis online dengan baik pada siklus kedua. Skor rata-rata penilaian kemampuan guru secara klasikal dalam mengisi dan mengupdate emis online mengalami peningkatan nilai rata-rata hasil Bimtek pada kondisi awal, siklus pertama dan siklus kedua dari sebesar 14,40 menjadi 22,80 dan 28,20 pada siklus terakhir dengan penjelasan kriteria nilai dari KURANG, meningkat menjadi CUKUP dan BAIK pada siklus terakhir.

Melihat data perolehan hasil penelitian dalam kegiatan penelitian tindakan sekolah ini, dapat disimpulkan bahwa Bimtek yang dilakukan oleh pengawas pendidikan agama Islam terhadap 18 guru SMK di wilayah Kabupaten Lombok Barat dinyatakan, berhasil meningkatkan kemampuan guru pendidikan agama Islam dalam mengisi dan mengupdate emis online.

\section{DAFTAR PUSTAKA}

Arikunto, Suharsimi. Research Procedure a Practical Approach. Jakarta: Rineka Cipta, 2010.

Aziz, Fuadi. "Pengambilan Kebijakan Berbasis Education Management Information System (EMIS)." Jurnal Pendidikan Islam 3, no. 1 (2014): 135-162.

Kementerian AgamaKantor Kabupaten Lombok Barat, http: // www. kemenaggeka. net/ page/ pais.html, [13 April 2016].

Purwanto, M. Ngalim. Evaluasi Dan Supervisi Pendidikan. Jakarta: Fakultas Ilmu Pendidikan, 1987.

Sugiyono. Metode Penelitian Kuantitatif Kualitatif Dan R\&D. Bandung: Alfabeta, 2012.

Syamsi, Ibnu. Pengambilan Keputusan Dan Sistem Informasi. Bumi Aksara, 1995.

Syarip, Dodi Irawan dan Rosidin. Sistem Manajemen Data Dan Informasi Pendidikan Di Lingkungan Direktorat Jenderal Kelembagaan Agama Islam. Jakarta: Departemen Agama RI; Direktorat Jenderal Kelembagaan Agama Islam, 2003.

Taggart, Kemmis dan Mc. The Action Research Planner. Victoria: Deaklin University, 1998.

Villanueva, Charles C. "Education Management Information System (Emis) and the Formulation of Education for All (Efa) Plan of Action." Unesco 1, no. 1 (2003): 1-60. 
Jurnal Penelitian Keislaman Vol.16 No.2 (2020): 103-116

"Manual Prosedur Bimbingan Teknis (BIMTEK)." Malang: Lembaga Penelitian dan Pengabdian Kepada Masyarakat (LPPM) Universitas Brawijaya Malang, 2015. 